\title{
Organizational Care and Support of Sheltered Street Children
}

\author{
Dr. G. Sarvani ${ }^{1 *}$
}

\section{ABSTRACT}

The present study is to find out the organizational care and support of sheltered street children. The sample consist 444 respondents. 176 are from government shelters, and 268 are from non government shelters. For this purpose Organizational care and support developed by researcher were used. The data obtained were analyzed through t- test to know the mean difference between the government and non government groups. Government sheltered street children have more health problems, more organizational facilities and less social support than non government sheltered street children.

Keywords: Organizational Care and Support, Sheltered Street Children, Government and Non Government, $t$ - Test.

A street child in India is a child in India "for whom the street (in the widest sense of the word, including unoccupied dwellings, wasteland, etc.) has become his or her habitual abode and/or source of livelihood; and who is inadequately protected, supervised, or directed by responsible adults". In the early years, the term "street child" included any child that worked on the street. From research, however, different categories of children on the streets have been distinguished, while still recognizing that children's complex experiences are difficult to define. (Thomas de Benítez, Sarah, 2007).

The term "Street Children" sounds a very narrow sense that may suggest children popularly known as 'rag pickers' in India, 'parking boys' in Kenya, 'peggy boys' in the Philippines, 'pivetes' in Brazil, 'pajaro frutero' in Peru and 'homeless youth' or 'runaways' in some developed countries ( Agarwal, R., 1999). While all these terms do qualify as street children, their descriptions do not constitute an adequate meaningful working definition.

\section{Ministry of welfare for street children}

Sincere efforts of various social organizations and non-governmental organizations pressured the national government to involve for the welfare of the street children. The term "street child" did

\footnotetext{
${ }^{1}$ Lecturer, Dept. of Psychology, Dr. L.B college of education

*Responding Author

(C) 2016 I G Sarvani; licensee IJIP. This is an Open Access Research distributed under the terms of the Creative Commons Attribution License (http://creativecommons.org/licenses/by/2.0), which permits unrestricted use, distribution, and reproduction in any Medium, provided the original work is properly cited.
} 


\section{Organizational Care and Support of Sheltered Street Children}

not figure in the "Official Vocabulary" of post independent India. Because of the pressure from the non-governmental organizations in the field of assistance to street children at both national and international level, the Government of India also had taken a positive view to set up a "Scheme for Assistance to Street Children" under ministry of welfare, which was implemented and launched in February, 1993. Initially, the Scheme was sanctioned and implemented in only six major cities as pilot study.

A series of meetings were held between non-governmental organizations and government officials, prior to the launching this scheme. A suitable frame work was evolved, and it was later modified taking into account the suggestions from different agencies, however, all these are not included in the final draft, thus leaving the Scheme incomplete and ineffective. But with certain changes, the scheme was accepted for implementation with conditions that the applicants (nongovernment organizations) should have three years minimum experience in the field of care and support for street children. It was observed and found that most of the applicants, as nongovernment organizations, have not worked in the field of street children. But with a political clout, most of the non-government organizations claimed for the development of street children and received large amount of grants towards launching homes for street children. But it did not yield expected results.

In the year of 2010 the government of India started new program that is Integrated Child Protection Scheme (ICPS). The objective of this program is to set in place child protection services in every district of the country. Preliminary feedback indicates that the program is hugely under -resourced, and already lagging in its implementation. Most juvenile homes today are fraught with problems which include poor infrastructure, unskilled personnel and a lack of specialized professionals like psychiatrists, psychologists, therapists and counselors.

\section{Government and Non-Government Organizations for Street Children in India}

The municipal corporations are, showing some interest in the plight of street children. Studies show that there are more small programs for street children in the country today than ever before and that some are either located in municipal buildings or assisted by the local body (i.e. Visakhapatnam, Vijayawada, Hyderabad, Chennai etc.). Government / non-government organizations jointly established CHILDLINE project a 24-hour, free, emergency telephone HELP LINE in 29 cities, and reported used by more than one million children in past 5 years.

Both the government and non-government organizations shelters aim to develop the child physically, emotionally, psychologically, socially and morally, thus enabling them to settle comfortably in the society. At present, government shelters are providing residential programs for street children while the non-government organizations shelters are providing drop-in-center and residential program for street children. The government shelters provide school education within the shelter; whereas, children sheltered in nongovernment organizations are sent to public and private schools. 


\section{Organizational Care and Support of Sheltered Street Children}

\section{Drop- in -center}

When required, children on the street can visit the drop-in-centre to avail the services for meeting their immediate needs. Various facilities like counseling, basic health care, savings, non-formal education, recreation, a missing children's bureau, water etc. are provided in the drop-in-centers. The aim and objective of these centers is to provide immediate and short- term assistance to the children.

\section{Residential program}

Though, an institution is definitely not the best place for a child to be in as compared to the family, it does substitute for those on the streets without one. For the young children who come from various parts of India to Hyderabad and Vijayawada with the aim of earning a better living, become rag pickers, beggars, shoe shine boys etc. Here living in a group they develop a sense of belonging, safety and new friends. The main focus of this is to provide street children with the opportunity of a safe shelter and to acquire educational or vocational skills. It also helps them to get in contact with their natural family and reunite them if possible and assist them to settle down independently in the society.

In shelters of government and non-government organizations, the field workers collect the children from the neighboring places and enroll them in the shelters. Sometimes, public and police also enroll street children; it also happens that parents enroll their children because the children wander on roads. A 24hrs telephone helpline known as CHILDLINE provides emotional assistance to street children and through this CHILDLINE, some children are referred to the shelters.

The need for love, as well as for security, is a powerful motivator of behavior (Brendtro et al., 1990). Alienated youths, experiencing harsh social conditions, may seek alternative ways to fulfill these needs, including running away. Young people also desire autonomy. For many street children, freedom from adult control is the most important attribute of their adopted way of life (Scharf et al., 1986). Street children who experience harsh social conditions and broken family relations tend to have behavioral problems. They seek alternative ways to fulfill their needs, by running away from their homes. Pringle (1974) grouped the psychosocial needs of children into four main areas: i) the need for love and security, ii) the need for new experiences, iii) the need for praise and recognition and iv) the need for responsibility. If these needs are not met or are thwarted, children may be at risk for emotional and behavioral problems, and fulfillment sought elsewhere (away from the family unit). Street children may fall into this category.

\section{Organizational care and support}

Once when the children leave their homes, psychologically they are pathetic, they need emotional support and they face many difficulties in street life. When they are enrolled in any organization, they expect some care, support and protection and usually they dislike too much security in shelters. Hence, the care and support provided by the organization and past 


\section{Organizational Care and Support of Sheltered Street Children}

experiences like familial and personal problems have a significant influence on the behavioral problems of street children. If the children receive proper care and support by organization, they feel happy, comfortable and become normal individuals. Different organizations are rendering some kind of support to street children. The fact remains that a street child is "a child" who should be assisted by parents and the school in his process of becoming an adult. This crucial factor is at present often over looked by these organizations that render support. These support structures direct their attention to activities that often exclude the school and the family context which are crucial in the child's becoming. The actualization of the child's full potential therefore becomes more remote.

Shelters run by the government and non-government organizations provide care, protection, support, education, development, employment, and rehabilitation of street children. Street children shelters are preferred over adult shelters and street outreach encourages youth to seek help when they might otherwise stay on the street. Mentors provide sympathetic listening and encouragement, as many youth are without a caring adult in their lives. Counseling helps the youth come to terms with painful life experiences.

Hackman \& Marcia Jean (2002) explored the process of homeless youth leaving street life and becoming independent. It is reported that moving to a shelter where they can have a safe environment in which they can self examine their past and present circumstances is quite welcome. They try to contemplate on what kind of future they would like to have. Other themes follow the process of moving to a shelter and include listening, privacy, absent parents, substance abuse, mental illness, achievement and forming an identity. Homeless youth who attempt independence before they have dealt with their past and present life experiences may fail to become or remain independent. Leaving street life was initiated by the youth as they began to care more about themselves than what other street youth thought of them. Helping the troubled families to deal with conflict may decrease the number of youth on the street, as would support families in order to keep children and youth in the home instead of removing them to an overburdened foster care system.

Lam, Debbie \& Cheng, Fucai (2008) examined the effectiveness of the government-managed Protection and education centre for street children in Shanghai. The study shows that most of the street children disliked the high security of the centre and many had rejected going home. So they tended to keep away from the centre even though it could provide them with lodging and food. It is suggested that the policy for street children should be reviewed with consideration given to street children's family situations and the children's own thoughts and preferences. The programs at the centre should be enriched and training of staff should be provided.

Cowan, Beryl Ann (2008) studied the association between traumatic exposure and mental health outcomes in sheltered homeless children. It is found that lifetime trauma exposure and homeless specific complex stress independently accounted for a significant amount of the variance in 


\section{Organizational Care and Support of Sheltered Street Children}

symptoms of depression, anxiety, aggression, and post traumatic stress. Life time trauma alone accounted for the variance in anger and anxiety related symptomatology. Perceived social support was found to have no influence on mental health morbidity. These findings point at the design of clinical interventions for this vulnerable population of children, in view of the important public policy implications.

Gewirtz et al. (2008) assessed the psychosocial and health status of formerly homeless children living with their families. Findings indicated that children had good access to physical health care; however, they faced significant psychosocial risks and manifested behavioral, emotional, and school challenges. Housing agencies lacked infrastructure or expertise in children's mental health. The authors proposed that supportive housing provides a valuable but hitherto under used opportunity to support children's psychosocial functioning.

\section{Scope}

In India there are a number of shelters for street children in many cities. However, the shelters located in Hyderabad and Vijayawada are promising Hyderabad is one of the largest metropolitan cities in India. As the city developed in all areas i.e. Information technology, industries, Whole sale markets and real estate etc, many opportunities are available for people to make their life comfortable Vijayawada is another major city and is a main railway junction. The city assumed a lot of commercial importance due to textile trade and agriculture. Many street children migrate to these cities lured by the city life and most of them seek shelter in any government or nongovernment organizations. As the services of these shelters are promising, the study has been confined to these two cities.

\section{OBJECTIVE OF THE STUDY:}

- To examine the organizational care and support between sheltered street children in government and non -government.

\section{Sample}

- The sample for the present study belongs to the lower socio economic status with similar background in family living style has been chosen. The sampling procedure adopted is more or less purposive. Out of the total 444 respondents, 176 are from government shelters and 268 are from non-government shelters. The average mean age of the participants is about 17.

\section{Tools}

Organizational care and support developed by researcher The items Of aspects in the questionnaire are classified into six categories; viz., physical facilities, educational facilities, health problems social support peer group support and moral support A total of 55 items were selected for their diversity in relevance to organizational care and support Each item was represented as a single statement. Respondents were asked to rate each item on a five point likert 


\section{Organizational Care and Support of Sheltered Street Children}

scale- where a score of 'one' indicates strongly disagree and 'five' indicates strongly agree, with intermediary scores of undecided. Reverse scoring was given for some of the negative statements present in the questionnaire.

\section{ORGANIZATIONAL CARE AND SUPPORT}

Organizational care and support is one of the important factors, which positively influence the lives of the street children. It has been observed that only three out of seven factors affect the life of street children, they are (i) health problems, (ii) organizational facilities and (iii) social support. The difference with regard to the remaining four factors - (i) physical facilities, (ii) schooling, (iii) organizational procedures and (iv) peer group support are not significant because these factors indicate similar attributes in both the shelters. In this section influence of first three factors mentioned above that revealed significant difference in organizational care and support discussed.

\section{Health problems}

Street children in the government shelters have health problems viz., visual, hearing dental, skin, physical illness and sleeping problems. It is observed that street children in government shelters have high score on health problems $(t=4.169 ; \mathrm{p}<0$ 01) than the street children in non government shelters (Table). Street children in the government shelters are facing high rate of health problems due to malnutrition, unhygienic conditions and lack of health consciousness. Street children in the non government shelters have lesser health problems due to the provision of nutritious food, hygienic environment and developing healthy habits by attending health awareness programs.

One recent study by Zena, A. and Aneth, K. (2010) supports the above observations. This study revealed that, street children frequently experience illness, particularly fever, skin diseases, injuries, headaches, diarrhea and stomach upsets.

\section{Organizational facilities}

The mean values indicate that the street children in government shelters have more organizational facilities $(t=2.31 ; \mathrm{p}<0$ 05) than street children in non government shelters (Table). Street children in government shelters are being provided with organizational facilities such as vocational training and guidance \& counseling. Street children in the non government shelters do not have such organizational facilities. Although some non government shelters provide guidance \& counseling and library facilities, they are not at an adequate level. 
Table 1, Difference between government and non government shelters of street children on the organization care and Support

\begin{tabular}{|c|c|c|c|c|}
\hline Organization care $\&$ support & Organization & Mean & S.D & $t$-value \\
\hline \multirow[t]{2}{*}{ Physical facilities } & GOVT & 43.34 & 6.17 & \multirow[b]{2}{*}{0.27} \\
\hline & NGO & 43.17 & 6.36 & \\
\hline \multirow[t]{2}{*}{ Schooling } & GOVT & 25.02 & 5.32 & \multirow[b]{2}{*}{1.30} \\
\hline & NGO & 24.35 & 5.36 & \\
\hline \multirow[t]{2}{*}{ Health problems } & GOVT & 1578 & 7.11 & \multirow[b]{2}{*}{$4.16^{* *}$} \\
\hline & NGO & 13.01 & 6.63 & \\
\hline \multirow[t]{2}{*}{ Organization al } & GOVT & 33.80 & 5.85 & \multirow[b]{2}{*}{0.10} \\
\hline & NGO & 33.74 & 5.33 & \\
\hline \multirow[t]{2}{*}{ Peer group support } & GOVT & 25.01 & 455 & \multirow[b]{2}{*}{-0.18} \\
\hline & NGO & 25.08 & 3.72 & \\
\hline Organizational & GOVT & 20.56 & 417 & \multirow{2}{*}{$2.31 *$} \\
\hline facilities & NGO & 19.54 & 478 & \\
\hline Social & GOVT & 26.94 & 5.63 & \multirow{2}{*}{$-3.48 * *$} \\
\hline support & NGO & 28.60 & 434 & \\
\hline
\end{tabular}

Sample size GOVT=176, NGO=268 ${ }^{*} \mathrm{p}<.05,{ }^{* *} \mathrm{p}<.01$

\section{Social support}

Street children in both the government and non government shelters are differ significantly with regard to the social support Street children in non government shelters are reporting more social support $(\mathrm{t}=3.48 ; \mathrm{p}<0$ 01) than the street children in government shelters (Table). The street children in non government shelters perceive more social support in the form of sharing feelings, taking advices and suggestions from friends, teachers and warden. Thus, these children are more enthusiastic, encouraging and helping each other. They bother about other problems and never exhibit any discrimination among themselves. On the other hand, street children in government shelters have less social support because of the employees in government shelters are permanent job holders and may not show commitment to serve children and extend support. Custodial care (often through juvenile justice system) may not provide required social support to the children. 


\section{Organizational Care and Support of Sheltered Street Children}

A study by Cowan. Beryl Ann (2008) do not support the above observation. The study was aimed at examining the association between traumatic exposure and mental health outcomes in sheltered homeless children. It also investigated the moderating role of perceived social support in the pathway between traumatic exposure and emotional distress. Hierarchical multiple regressions revealed that perceived social support has no influence on mental health morbidity.

The street children in government shelters have more health problems, receive organizational facilities and have less social support while street children in the non government shelters have experience health problems, receive less organizational facilities and have more social support.

\section{RECOMMENDATIONS}

- Government and non government organizations should start more help lines for street children in metropolitan cities.

- Runaway children need more emotional support and require proper personal counseling.

- Government should provide free and quality education to the street children with low socio economic background.

- Government should start more shelters for street children and their parents. It is very helpful to the homeless families as their children can get more support, strength and well behave under the supervision of their parents.

\section{REFERENCES}

Agarwal R. (1999). Street Children. 1st ed, New Delhi, Shipra Publications.

Brendtro, L. K, Brokenleg, M. \& Van Bockern, S (1990): Reclaiming youth at risk, Bloomington IN: National Education Service.

Cowan, BerylAnn. (2008): Trauma exposure and behavioral outcomes in sheltered homeless children: The moderating role of perceived social support. Dissertation. Abstracts International: Section B: The Sciences and Engineering 68(12-B) pp 8393.

Gewirtz, Abigail, Hart-Shegos, Ellen, Medhanie \& Amanuel. (2008): Psychosocial status of homeless children and youth in family supportive housing, American Behavioral Scientist 51(6) pp 810-823.

Hackman, Marcia Jean. (2002): Lost in the woods: Homeless youth leaving street life. Dissertation Abstracts International: Section B: The Sciences and Engineering 63(3-B) pp. 1268.

Lam, Debbie \& Cheng, Fucai.(2008): Chinese policy reaction to the problem of street children: An analysis from the perspective of street children. Children and Youth Services Review 30(5) pp 575-584.

Pringle, M. K. (1974). The needs of children. London: Hutchinson.

Scharf, W., Powell, M., \& Thomas, E. (1986): Strollers: Street children of Cape

Town. In S. Burman \& P. Reynolds (Eds.), Growing up in a divided society: The context of childhood of South Africa. Johannesburg: Ravan Press. 
Thomas de Benítez, Sarah (2007): State of the world's street children Consortium for street Children. http://www.streetchildren.org.uk/content.asp

Zena Amury \& Aneth Komba (2010): Coping strategies used by street children in the event of illness. Research on poverty Alleviation. Research report 10/1.

\section{Websites:}

www.emdh.com general information about street children Retrieved on2010.

www.shelterdonbosco.org causes of street children, Retrieved on 2009.

www.streetchildren.org.uk, street children in United Kingdom, Retrieved on2009.

www.SKCV.com Manihar M. Indian street children, Retrieved on 2008.

www.slc.sevier.org,Emotional and Behavioral problems of street children,

Retrieved on 2007. 